It was Dr. Fish, and not Dr. Burgess.

MilwaukeE, Wis., Oct. 5, 1895.

To the liditor:-In your issue of the 5 th inst., you state on page 578 that Dr. A. J. Burgess of Milwaukee said " so.andso." These remarks, abbreviated though they be, were mine. I believe I am the only Fellow of the American Association of Obstetricians and Gynecologists in this State-and at least the only one present at this discussion. I most decidedly object to jour quoting some one else for me, or your attributing remarks to me made by another.

$$
\text { Yours truly, } \quad \text { E. F. Fish, M.D. }
$$

The McDowell Biography.

New Orleans, Oct. 4, 1895.

To the Editor:-Some time ago, over one year, a lady came to my office soliciting subscriptions to the biography of Ephraim McDowell, M.D., claiming among other things, that she was a distant relative of the Doctor. I find my receipt for the price of said book, but no book yet. I do not believe the Doctor would approve of such slow treatment or action. As I have not her address, and I noticed some time since you had, would you kindly send this to her, or to those in charge of publication, and oblige,

S. L. Henry, M.D.

\section{Some Recent Comments on the Journal.}

The Opinion of ax Old Member.

Le Mars, Iowa, Sept. $8,1895$.

To the Editor:--Your publication of letters on the line of "What I know about the JournaL," is correct, and some of the criticisms are good. There is an abundance of medical periodicals of the "featherweight" variety in existence, such as would suit quite a sprinkling of our profession, but for physicians who are eligible to membership in the AMErICAN Medrcal Association, a journal like ours is not too scientific or too heavy. If all those who now disagree with me will but read the Journal for a few months, they will soon feel the necessity for that class of medical literature. A page or two each week of light practical reading, as suggested by Dr. Towler, would certainly not be considered amiss by any one, and might make the Jovnat more popular with some. As long as we have our editor to act as sifting committee, there will be no danger of articles finding their way into the Jour$\mathrm{xAL}$ which would make it a laughing stock to the profession or to other periodicals. I have in my library every issue of our Journal, from No. I to the present, and could not spare a single number.

PaUl L. Brick, M.D.

From A Health OFFICER.

Wooster, Ohio, Oct. 1, 1895.

To the Elitor:-What seemed more than an herculean task a few months since-and it was even doubted whether it could be done-the editing of the JocrnaL, is now grandly accomplished. The Jourvis to.day is the best educator the profession in America has ever had.

Glance over the articles it has contained for three or four months last past! Many of them are exhaustive on the sub. jects they discuss, and some bring to light new truths of great value to the profession.

Accept $\mathrm{m} y$ congratulations for your past success and $\mathrm{my}$ earnest wishes for your future usefulness. Fraternally, JoSEPH E. BARRETT, M.D. Health Officer.

\section{He Compliments the Journat.}

Columbus, Ohro, Oct. 5, 1895.

To the Editor:- . . . Permit me to compliment you on the Jounna in general, and particularly on your editorials. The editorial of two weeks ago on Basedow's disease I think especially good. While you did not solve the secret of the etiology and seat of that mysterious malady, you presented all that is known in a condensed and scholarly manner. Stakling Loving, M.D.

Dr. Quimby's Opinion.

To the Editor:- . . As time rolls on, our Journal, grows in value and importance, and if no obstacle is thrown in the way, is destined to be one of the greatest medical lights and journals of the age. $\quad$ I. N. Quimsy, M.D,

\section{NECROLOGY.}

Josept C. Gordon, M.D., of Mt. Vernon, Ohio, October 2, aged 54 . He was born in Chester County, Pa., and went to Knox County, Ohio, in 1853. He served through the Civil War in Company A, 20th Regiment O. V. I., and was prominent in Masonic circles.-Wm.H. Gibson, M.D., of Chariton, Iowa, October 3.-E. P. Gaylord, M.D., of Alameda, Cal., September 27, aged 61. He was formerly from New York and had lived in Alameda nearly three years.-F. M. Everett, M.D., of Corydon, Iowa, September 29, aged 65.- James Collins, M.D., of Philadelphia, October 7.

\section{PUBLIC HEALTH.}

Pollution of the Passaic River, New Jersey.-According to the Sanitarian for August, the health authorities of Passaic, N. J., have passed resolutions declaring that the pollution of the Passaic River by sewage and manufacturing refuse from the cities of Passaic and Paterson has reached the danger point. Every summer, City Physician Terhune says, there is an epidemic of malarial fevers among the residents along the river and the Dundee Canal, which the river supplies. The board called on the two cities to take steps to diminish pollution. The board advocates the building of a trunk sewer from Paterson to the sea.

Cost of Cremation in Now York.-The charge for cremating the body of an adult in New York city is $\$ 35$ and for that of a child $\$ 25$. Urns or vases vary in price from $\$ 6$ to $\$ 45$; the former are of bronze and white metal, the latter of serpentine stone, marble, etc. For $\$ 25$ a niche may be bought in the crematory where the urn will be cared for, or it may be taken possession of by the family. About one-half are said to be kept at the crematory; some are taken away and placed in safety deposit vaults and others are kept among the most sacred treasures of the home. A newspaper report has it that one relict carries the ashes of her deceased husband wherever she goes-to Europe and back several times and frequently to the seashore and mountains. It is not stated what rate of fare is charged for the " remains."

The New York City Board of Health's New Regulations.-The New York Board of Health has adopted rules for the prevention of the spread of contagious diseases among public school children. These rules decree that slates and slate pencils shall be abolished, and pens and pencils substituted, the latter to be kept in separate boxes by each pupil. All the school property of a child ill with a contagious disease shall be turned over to the health board. Books that are taken home shall be re-covered with brown paper once a month. Each class must have its own covered pitcher for drinking water, and each pupil a separate cup. In cases of contagious disease in a family, the children are at once to be excluded, and teachers are to report weekly to the board the names and conditions of pupils who are ill. All teachers and principals shall be forbidden to send any pupil to the home of another pupil for any reason. Circulars of instruction to the Board of Education on those matters, and also to principals, are in the course of preparation. 